\title{
Expression and Significance of CD123 and CD96 in Myelodysplastic Syndrome
}

\author{
Zhang Xuefang * \\ The Hematology \& Rheumatism Department \\ The Second Affiliated Hospital of Qiqihar \\ Medical University \\ Qiqihar, China \\ xufang3722@126.com \\ * Corresponding Author \\ Zhang Shuying \\ The Hematology \& Rheumatism Department \\ The Second Affiliated Hospital of Qiqihar \\ Medical University \\ Qiqihar, China \\ springyc@163.com \\ Zhou Hong \\ The Hematology \& Rheumatism Department \\ The Second Affiliated Hospital of Qiqihar \\ Medical University \\ Qiqihar, China \\ lgtong@163.com
}

\author{
Jiang Libo \\ The Hematology \& Rheumatism Department \\ The Second Affiliated Hospital of Qiqihar \\ Medical University \\ Qiqihar, China \\ candyjingq@163.com
}

\author{
Guo Heng \\ The Hematology \& Rheumatism Department \\ The Second Affiliated Hospital of Qiqihar \\ Medical University \\ Qiqihar, China \\ fanhyou@163.com,
}

\author{
Wang Suliang \\ The Hematology \& Rheumatism Department \\ The Second Affiliated Hospital of Qiqihar \\ Medical University \\ Qiqihar, China \\ junjie0686@163.com
}

Keywords: Myelodysplastic Syndrome; CD123; CD96; Immunophenotype; Flow Cytometry

\begin{abstract}
Objective: To explore the relationship between the expression of CD123 and CD96 and prognosis in MDS. Methods: 89 MDS patients and 20 controls are enrolled. The patients are grouped by the risk. All participants are detected by bone marrow biopsy. Mononuclear cells are extracted, CD34+CD38-CD123+ and CD34+CD38-CD96+ cells are counted by flow cytometry. Expression of the two types of cells in control group, observation group and its subgroups are analyzed. Results: MDS patients display significantly larger proportion of CD34+ cells and CD34+CD38- cells than that of controls $(\mathrm{P}<0.05)$ and the proportion increases with the risk. In the low-and middle-risk group, the rates of complete remission (CR ) and partial remission (RR) are significantly higher in CD123CD96- cells than that in CD123+CD96+ cells. In the middle-and high-risk patients group, RR is significantly higher in CD123- cells than that in CD123+ cells $(\mathrm{P}<0.05)$ and $\mathrm{CR}$ is significantly higher in CD96- cells than that in CD96+ cells $(\mathrm{P}<0.05)$. Conclusion: The differentiation of CD34+ cells in bone marrow of MDS patients is abnormal, with the high expression of CD123 and CD96 cells. These findings might partly explain the cause of MDS patients with hematopoietic stem cells malignant clone.
\end{abstract}

\section{Introduction}

Myelodysplastic syndromes (MDS) are a heterogen-ous group of clonal disorders. Bone marrow cells with unilineage dysplasia or multilineage dysplasia exists ab-rrated in both of differentiation and 
development in patients with MDS. Clinical characteristics of MDS are hematopoietic dysplasia with increased number of pro-aemocytes. It is more difficult to diagnose MDS at present, while it becomes significant to find a marker for MDS clones in the early stage and to explore a new therapeutic strategy [1]. A study reported trace amounts of leukemia stem cells (LSC) were found in the bone marrow of patients with acute myeloid leukemia, which was the mainly reason for the recurrence of leukemia and drug resistance [2]. Further studies found that there were two kinds of more specific markers: $\mathrm{CD} 34^{+} \mathrm{CD} 38^{-} \mathrm{CD} 123^{+}$and $\mathrm{CD} 34^{+} \mathrm{CD} 38^{-} \mathrm{CD} 96^{+}[3]$. Nowadays, whether MDS patients have the similar special immunophenotype is a key point of the relevant researches. This study aims to identify the relationship between the expression of CD123 and CD96 and prognosis of MDS patients. The results are shown as follows.

\section{Materials and Methods}

Study Subjects. This study had obtained ethics committee approval by the ethics committee of the hospital. 89 patients with MDS (54 males and 35 females, aged 33 79 years old, mean age 64.6 \pm 9.3 years old) were recruited as observation group from the hematology department of our hospital in the period between July 2012 and June 2014. According to the diagnosis standard of "Standards for diagnosis and curative effect of blood diseases", the 89 cases included 43 patients with acquired refractory anemia with excess blasts (RAEB) (28 RAEB-1, 15 RAEB-2), 22 patients with refractory cytopenia with multilineage dysplasia (RCMD), 15 patients with refractory anemia with ring sideroblast (RARS) and 9 patients with refractory anemia (RA). In accordance with the international prognosis scoring system (IPSS), MDS patients were subgrouped by the risk. Thirty-two patients were in the low-and middle1-risk group and fifty-seven were in the middle2- and high-risk group. Meanwhile, 20 healthy subjects (12 males and 7males, aged 35 73, mean age 61.2 \pm 7.9 ) without blood disease were enrolled as controls. All patients in the observation group were initially diagnosed with MDS and control subjects had normal bone marrow. Individuals with the following conditions were excluded from this study: (1) tumor-bearing status or had other tumors before; (2) received radiotherapy or chemotherapy treatments; (3) uninitial diagnosed with MDS and received other treatments, such as traditional Chinese medicine, Tibetan medicine, etc. The study was approved by the hospital ethics committee, and all subjects signed the informed consent.

Reagents and Equipment. PerCP-labelled mouse anti-people CD34 mAb; APC-labelled mouse anti-people CD38 mAb; FITC-labelled mouse anti-people CD123 mAb; FITC-labelled mouse antipeople CD96 mAb and their isotype matched control mAbs, respectively. Flow cytometry (EPICS ALTRA). The above mentioned reagents and equipment were produced by Becton, Dickinson and Company (BD)

Experiment Method. After the local anesthesia or multi subcutaneous anesthesia, bone marrow $(2 \mathrm{ml})$ was extracted from anterior superior iliac spine and was drown into a heparin tube. Bone marrow was filtered with 200 mesh copper grids, then the filtrate was divided into 100ul per tube. CD34、CD48、CD96、CD114 and CD123 were separately added 20ul into test tubes before, and then they were mixed with 100ul bone marrow. Their isotype control mAbs were separately added $20 \mathrm{ul}$ into negative control tubes, after that they were mixed uniformly with $100 \mathrm{ul}$ bone marrow. All the mixed liquor was placed at $4{ }^{\circ} \mathrm{C}$ refrigerator and was taken out after 30 mins.. $2 \mathrm{ml}$ erythrocyte lysis buffer was added to each tube, mixed uniformly, incubated for $10 \mathrm{mins}$. at $20^{\circ} \mathrm{C}$ and centrifuged for $10 \mathrm{mins}$ at $2000 \mathrm{r} / \mathrm{min}$. The supernatant was discarded and the pellet was resuspended in $2 \mathrm{ml}$ phosphate buffer (PBS), shaked vigorously, and centrifuged for $10 \mathrm{mins}$. at 2000 r/min. The supernatant was discarded and the pellet was resuspended in $0.3 \mathrm{ml}$ PBS. After washing again, it was centrifuged for $10 \mathrm{mins}$. at 2000r/min. Filtering the cell suspension with 400 mesh copper grids, then the filtrate was tested with flow cytometry. Cells collected were $(5 \sim 10) \times 105$ for each sample. 
Treatment and Evaluation Methods. All patients took oral preparation of cyclosporine A with thalidomide as basic treatment: the initial dosage of cyclosporine A was $3 \mathrm{mg} / \mathrm{kg} / \mathrm{d}$ and thalidomide was $200 \mathrm{mg} / \mathrm{d}$. After clinical observations on side effects of drugs, increasing $100 \mathrm{mg}$ every week if it could be accepted, the maximum dose was $600 \mathrm{mg} / \mathrm{d}$. Additionally, the low-and middle-risk patients group was treated with hematopoietic stimulating factors, such as erythropoietin (EPO) 、 granulocyte colony-stimulating factor (G-CSF), and the middle-and high-risk patients group adopted the IA chemotherapy (idarubicin 10mg/d1-3, cytarabine 200mg/d1-7), arsenotherapy, decitabine treatment and other related symptomatic treatment. The judgment standard of therapeutic effect was referred to 'Standards for diagnosis and curative effect of blood diseases, including (1) complete remission (CR): clinical symptoms disappeared, blood routine went back to normal, myelogram went back to normal or near-normal, the original naïve cells were $<5 \%$; (2) partial remission (PR): clinical symptoms were relieved, unilineage dysplasia got back to normal at least, original naïve cells of myelogram were 5\% 20\%; (3) non-remission (NP): clinical symptoms were not relieved or got worse, mutilineage dysplasia, the original naïve cells of myelogram were $>20 \%$. Remission rate $(\mathrm{RR})=($ case number of CR + case number of PR) / all cases $\times 100 \%$.

Statistic Analysis. Statistical analysis was performed by SPSS19.0 software. Measurement data were analyzed by Paired Student's test. Those measurement data which did not match the normal distribution were analyzed by Nonparametric Text. Enumeration data were tested with the chi-square $(\chi 2)$ goodness-of-fit test. All the data were in the form of $\left(\mathrm{x}_{\mathrm{x}} \mathrm{s}\right) . \mathrm{P}<0.05$ indicated a statistically significant difference.

\section{Results}

The Proportion of CD34+ Cells and CD34+CD38- Cells in Each Group of Subjects. Bone marrow mononuclear cells of MDS patients displayed significantly larger proportion of CD $34^{+}$cells and $\mathrm{CD} 34^{+} \mathrm{CD} 38^{-} / \mathrm{CD} 34^{+}$cells than that of normal controls $(\mathrm{P}<0.05)$. In the middle2-and high-risk patients group, the proportion of $\mathrm{CD} 34^{+}$cells and $\mathrm{CD} 34^{+} \mathrm{CD} 38^{-} / \mathrm{CD} 34^{+}$cells was significantly larger than that of the low-and middle-risk patients group $(\mathrm{P}<0.05)($ Table 1$)$.

TABLE 1 THE PROPORTION OF CD34 ${ }^{+}$CELLS AND CD34 ${ }^{+}$CD $38^{-}$CELLS IN EACH GROUP OF SUBJECTS (\%)

\begin{tabular}{|c|c|c|c|}
\hline Group Type & $\mathbf{n}$ & $\mathrm{CD34}^{+}$ & $\begin{array}{c}\mathrm{CD34}^{+} \text {CD38 } \\
\text { /CD34 }^{+}\end{array}$ \\
\hline Control group & 20 & $0.48 \pm 0.11$ & $7.44 \pm 1.91$ \\
\hline Observation group & 89 & $6.85 \pm 3.42 *$ & $\begin{array}{ll}23.29 & \pm \\
5.16^{*} & \end{array}$ \\
\hline $\begin{array}{l}\text { Low-and middle } 1 \\
\text { risk patients group }\end{array}$ & 32 & $2.44 \pm 1.07$ & $13.49 \pm 3.55$ \\
\hline $\begin{array}{l}\text { Middle2-and high } \\
\text { risk patients group }\end{array}$ & 57 & $8.69 \pm 2.31 \#$ & $\begin{array}{ll}29.64 & \pm \\
4.83 \# & \end{array}$ \\
\hline
\end{tabular}

The Proportion of CD34+CD38- cells and CD123+CD96+ Cells in Each Group of Subjects. The expression rates of $\mathrm{CD} 34^{+} \mathrm{CD} 38^{-} \mathrm{CD} 123^{+} / \mathrm{CD} 34^{+} \mathrm{CD} 38^{-}$and $\mathrm{CD} 34^{+} \mathrm{CD} 38^{-} \mathrm{CD}^{-} 6^{+} / \mathrm{CD} 34^{+} \mathrm{CD} 38^{-}$ were significantly higher in MDS patients than that in normal controls $(\mathrm{P}<0.05)$. In the middle2-and high-risk patients group, the proportion of $\mathrm{CD} 34^{+} \mathrm{CD} 38^{-} \mathrm{CD} 123^{+} \mathrm{CD} 34^{+} \mathrm{CD} 38^{-}$and $\mathrm{CD} 34^{+} \mathrm{CD} 38^{-}$ $\mathrm{CD}^{\circ} 6^{+} / \mathrm{CD} 4^{+} \mathrm{CD} 38^{-}$was significantly larger than that of the low-and middle1-risk patients group $(\mathrm{P}<0.05)$ (Table 2). 
TABLE 2 THE PROPORTION OF CD $123^{+}$AND CD $96^{+}$CELLS AMONG CD $34^{+}$CD $38^{-}$CELLS IN EACH GROUP OF SUBJECTS (\%)

\begin{tabular}{|c|c|c|c|}
\hline Group Type & $\mathbf{n}$ & $\begin{array}{c}\mathbf{C D 3 4}^{+} \mathbf{C D 3 8}^{-} \\
\mathbf{C D 1 2 3}^{+} \text {/ } \\
\mathbf{C D 3 4}^{+} \mathbf{C D 3 8}^{-}\end{array}$ & $\begin{array}{c}\mathbf{C D 3 4}^{+} \mathbf{C D 3 8}^{-} \\
\mathbf{C D 9 6}^{+} / \\
\mathbf{C D 3 4}^{+} \mathbf{C D 3 8}^{-}\end{array}$ \\
\hline Control group & 20 & $8.76 \pm 6.47$ & $10.82 \pm 4.69$ \\
\hline $\begin{array}{c}\text { Observation } \\
\text { group }\end{array}$ & 89 & $32.94 \pm 9.28^{*}$ & $23.41 \pm 8.06^{*}$ \\
\hline $\begin{array}{c}\text { Low-and } \\
\text { middle1 risk } \\
\text { patients group }\end{array}$ & 32 & $16.30 \pm 5.83^{*}$ & $12.53 \pm 7.11$ \\
\hline $\begin{array}{c}\text { Middle2-and } \\
\text { high risk } \\
\text { patients group }\end{array}$ & 57 & $38.42 \pm 8.70^{*}$ & $27.65 \pm 8.49 *$ \\
\hline
\end{tabular}

Note: Compared with the control group, $* \mathrm{P}<0.05$; compared with the low-and middle1 risk patients group, $* \mathrm{P}<0.05$

TABLE 3 THE THERAPEUTIC EFFECT OF TWO SUBGROUPS[N, (\%)]

\begin{tabular}{|c|c|c|c|c|c|}
\hline Group Type & $\mathbf{n}$ & CR & PR & NR & RR \\
\hline $\begin{array}{c}\text { Low-and middle1 risk } \\
\text { patients group }\end{array}$ & 32 & $12(37.50)$ & $15(46.88)$ & $5(15.63)$ & $27(84.38)$ \\
\hline $\begin{array}{c}\text { Middle2-and high risk } \\
\text { patients group }\end{array}$ & 57 & $12(21.05)$ & $28(49.12)$ & $17(29.82)$ & $40(70.18)$ \\
\hline
\end{tabular}

TABLE 4 THE THERAPEUTIC EFFECT OF DIFFERENT SUBTYPES OF CD34 ${ }^{+}$CD38- IN THE LOW-AND MIDDLE1 RISK PATIENTS GROUP [N, (\%)]

\begin{tabular}{|c|c|c|c|c|c|}
\hline Group Type & $\mathbf{n}$ & CR & PR & NR & RR \\
\hline $\mathrm{CD}^{+} \mathrm{CD} 38^{-\mathrm{CD} 123^{+}}$ & 21 & $5(23.81)$ & $11(52.38)$ & $5(23.81)$ & $16(76.19)$ \\
\hline $\mathrm{CD} 34^{+} \mathrm{CD} 38^{-\mathrm{CD} 123^{-}}$ & 11 & $7(63.64)^{*}$ & $4(36.36)$ & $0(0)$ & $11(100.00)^{*}$ \\
\hline $\mathrm{CD} 34^{+} \mathrm{CD} 38^{-\mathrm{CD} 96^{+}}$ & 18 & $4(22.22)$ & $10(55.56)$ & $4(22.22)$ & $14(77.78)$ \\
\hline $\mathrm{CD} 34^{+} \mathrm{CD} 38^{-} \mathrm{CD} 96$ & 16 & $8(50.00) \#$ & $7(43.75)$ & $1(6.25) \#$ & $15(93.75) \#$ \\
\hline
\end{tabular}

TABLE 5 THE THERAPEUTIC EFFECT OF DIFFERENT SUBTYPES OF CD34 ${ }^{+}$CD38- IN THE MIDDLE2-AND HIGH RISK PATIENTS GROUP [N, (\%)]

\begin{tabular}{|c|c|c|c|c|c|}
\hline Group Type & $\mathbf{n}$ & $\mathbf{C R}$ & $\mathbf{P R}$ & NR & RR \\
\hline $\mathrm{CD} 34^{+} \mathrm{CD} 38^{\circ} \mathrm{CD} 123^{+}$ & 31 & $5(16.13)$ & $14(45.16)$ & $12(38.71)$ & $19(61.29)$ \\
\hline $\mathrm{CD} 34^{+} \mathrm{CD} 38^{-\mathrm{CD} 123^{-}}$ & 26 & $7(26.92)$ & $14(53.85)$ & $5(19.23)^{*}$ & $21(80.77)^{*}$ \\
\hline $\mathrm{CD} 34^{+} \mathrm{CD} 38^{-} \mathrm{CD} 96^{+}$ & 36 & $5(13.89)$ & $19(52.78)$ & $12(33.33)$ & $24(66.67)$ \\
\hline $\mathrm{CD} 34^{+} \mathrm{CD} 38^{-} \mathrm{CD} 96^{-}$ & 21 & $7(33.33) \#$ & $9(42.86)$ & $5(23.81)$ & $16(76.19)$
\end{tabular}

Lineage Dysplasia from Unilineage Dysplasia, 3 Subjects Transformed into AML) (Table3). In the Low-and Middle1- The Comparison of two Subgroups of the Observation Group. In the low-and middle1-risk patients group, there were 12 cured subjects and 5 non-remission subjects (3 subjects transformed into RAEB from RA, 2 subjects transformed into AML); in the middle2-and high-risk patients group, there were 12 cured subjects and 17 non-remission subjects (6 subjects transformed into three-lineage dysplasia from two-lineage dysplasia, 4 subjects transformed into two-lineage dysplasia from unilineage dysplasia, 4 subjects transformed into three-lineage dysplasia from unilineage dysplasia, 3 subjects transformed into AML) (Table3). In the low-and middle1-risk 
patients group, $\mathrm{CR}$ and $\mathrm{RR}$ were significantly higher in $\mathrm{CD} 34^{+} \mathrm{CD} 38^{-} \mathrm{CD} 123^{-}$and $\mathrm{CD} 34^{+} \mathrm{CD} 38^{-}$ CD96 cells than that in the ${ }^{-} D 34^{+} \mathrm{CD} 38^{-} \mathrm{CD} 123^{+}$and $\mathrm{CD} 34^{+} \mathrm{CD} 38^{-} \mathrm{CD} 96^{+}$cells (Table4). In the middle2-and high-risk patients group, RR was significantly higher in the CD $34^{+} \mathrm{CD} 38^{-} \mathrm{CD} 123^{-}$cells than that in the $\mathrm{CD} 34^{+} \mathrm{CD} 38^{-} \mathrm{CD} 123^{+}$cells $(\mathrm{P}<0.05)$ and $\mathrm{CR}$ was significantly higher in the $\mathrm{CD} 34^{+} \mathrm{CD} 38^{-} \mathrm{CD}^{-} 6^{-}$cells than that in the $\mathrm{CD}^{+} 4^{+} \mathrm{CD} 38^{-} \mathrm{CD}^{+} 6^{+}$cells $(\mathrm{P}<0.05)$ (Table5).

\section{Discussion}

Myelodysplastic syndromes refers to a heterogeneous group of closely related clonal hematopoietic disorders. As a preleukemia statement, MDS can develop into acute myeloid leukemia (AML) [1]. It is difficult to diagnose MDS at present because part of patients do not show a change of cytogenetics and the number of prohaemocytes and dysplasia is increased [1,5]. In recent years, CD123 and CD96 were found to overexpress in studies about hematological malignances, such as AML and ALL-B $[6,7]$. Their expression level could not only reflect the initial cells proliferation but also indicate the preliminary estimation for adverse reactions of patients. Christopher et al. reported that the immunophenotype of CD34 and CD38 on the surface of leukemia stem cells were CD $34^{+} \mathrm{CD} 38^{-}$and $90 \%$ of $\mathrm{CD} 34^{+} \mathrm{CD} 38^{-}$cells express $\mathrm{CD} 123[8]$, while $\mathrm{CD} 34^{+} \mathrm{CD} 38^{-}$cells hardly express CD123 with normal physiological state. Therefore it could be speculated that CD123 might be the marker of LSC statement. During the examination of the immunophenotype of $\mathrm{CD} 34^{+} \mathrm{CD} 38^{-}$in $\mathrm{AML}$ patients, DeSmet et al. found that CD96 highly expressed in $\mathrm{CD} 34^{+} \mathrm{CD} 38^{-}$cells, however, normal hematopoietic stem cells could not detect the expression of CD96 [9]. In an animal experiment, Wilke divided CD34+CD38- cells into two groups: $\mathrm{CD} 34^{+} \mathrm{CD} 38^{-} \mathrm{CD} 96^{+}$cells and CD34+CD38-CD96- cells, then they were transplanted separately into beagle dogs. The result showed that only with $\mathrm{CD} 34^{+} \mathrm{CD} 38^{-} \mathrm{CD} 96^{+}$cells, the beagle dog acquired AML, so they concluded that CD96 could be the marker for identifying LSC [10].

To test whether LSC was the cause of MDS transforming into AML in patients, our study detected the immunophenotype of mononuclear cells from the bone marrow in 89 patients with MDS and 20 healthy controls. The result turned out that the proportion of $\mathrm{CD} 34^{+}$cells and $\mathrm{CD} 34^{+} \mathrm{CD} 38^{-}$ cells in the observation group was significantly larger than the control group $(\mathrm{P}<0.05)$. This result was consistent with the findings of Rollins-Raval [11]. It indicated that CD $34^{+}$abnormally differentiated in patients with MDS and it was correlated with the risk. In the middle2-and high-risk patients group, the proportion of CD34+CD38- cells was significantly larger than that in the low-and middle-risk patients group $(\mathrm{P}<0.05)$. It hinted that a positive correlation between the expression of $\mathrm{CD} 34^{+} \mathrm{CD} 38^{-}$cells and the risk of AML. Further study found that the expression rates of $\mathrm{CD} 34+\mathrm{CD} 38-\mathrm{CD} 123^{+} / \mathrm{CD} 34^{+} \mathrm{CD} 38^{-}$and $\mathrm{CD} 34^{+} \mathrm{CD} 38^{-} \mathrm{CD} 96^{+} / \mathrm{CD} 34^{+} \mathrm{CD} 38^{-}$were significantly higher in MDS patients than that in controls $(\mathrm{P}<0.05)$, which was similar to the results of Fromm [12]. Those findings gave us the clue that MDS patients had stem cells similar to LSC. That MDS turned into AML was probably due to the existence of CD123 and CD96 on the surface of $\mathrm{CD} 34^{+} \mathrm{CD} 38^{-}$cells and that may be associated with malignant clones of hematopoietic stem cells in MDS patients. The expression of CD34+CD38- CD123+ cells and CD34 ${ }^{+} \mathrm{CD} 38^{-} \mathrm{CD} 96^{+}$cells was associated with the risk, which was the same as $\mathrm{CD} 34^{+} \mathrm{CD} 38^{-}$cells. And there was no significant difference between the low-and middle1-risk patients group and the control group in the expression of $\mathrm{CD} 34^{+} \mathrm{CD} 38^{-} \mathrm{CD} 6^{+}$cells $(\mathrm{P}>0.05)$. On the contrary, $\mathrm{CD} 34^{+} \mathrm{CD} 38^{-} \mathrm{CD} 123^{+}$cells were significantly more than the control group $(\mathrm{P}<0.05)$. It indicated that $\mathrm{CD} 123$ was more sensitive and effective for the classification of the risk.

This study also did a statistic analysis in the prognosis of MDS patients. The result showed that in the low-and middle-risk patients group, the proportion of $\mathrm{CR}$ and RR were significantly larger in patients with $\mathrm{CD} 34^{+} \mathrm{CD} 38^{-} \mathrm{CD} 123^{-}$and $\mathrm{CD} 34^{+} \mathrm{CD} 38^{-} \mathrm{CD} 96^{-}$cells than with the $\mathrm{CD} 34^{+} \mathrm{CD} 38^{-} \mathrm{CD} 123^{+}$ and $\mathrm{CD} 34^{+} \mathrm{CD} 38^{-} \mathrm{CD} 96^{+}$cells. In the middle2-and high-risk patients group, RR rate was significantly higher in the CD34+CD38-CD123- cells than that in the CD34 ${ }^{+} \mathrm{CD} 38^{-} \mathrm{CD} 123^{+}$cells $(\mathrm{P}<0.05)$ and 
$\mathrm{CR}$ rate was significantly higher in the $\mathrm{CD}^{+} 4^{+} \mathrm{CD} 38^{-} \mathrm{CD} 96^{-}$cells than that in the $\mathrm{CD} 34^{+} \mathrm{CD} 38^{-} \mathrm{CD} 96^{+}$ cells $(\mathrm{P}<0.05)$. All of these indicated that patients with $\mathrm{CD} 123^{+} / \mathrm{CD} 6^{+}$developed drug resistance on hematopoietic stimulating factors or chemotherapeutic drugs and initially detected the prognosis of patients by CD123 and CD96.

\section{Conclusions}

CD34+ cells are differentiated abnormally in the bone marrow of patients with MDS, in which CD123 and CD96 are highly expressed. These findings might partly explain the existence of malignant clones in hematopoietic stem cells in MDS patients.

\section{Acknowledgment}

This study was supported by the fund of Qiqihar science and technology project(NO. SFGG201321) from Science and Technology Bureau of Qigihar. Heilongjiang Province, China.

\section{References}

[1] Kawankar N,Rao Vundinti B. Cytogenetic ab-normalities in myelodysplastic syndrome: an overview. [J]. Hematology, 2011,16(3):131-138.

[2] Tang,G.,Jorgensen,J.L.,Zhou,Y. et al. Multi-color CD34 ${ }^{+}$progenitor-focused flow cytometric assay in evaluation of myelodysplastic syndromes in patients with post cancer therapy cytopenia [J]. Leukemia Research: A Forum for Studies on Leukemia and Normal Hemopoiesis, 2012, 36(8): 974-981.

[3] Lin,J.,Chen,S.,Zhao,Z. et al. CD123 is a useful im-munehisto chemical marker to facilitate diagnosis of acute graft-versus-host disease in colon [J]. Human Pathology, 2013, 44(10): 20752080.

[4] Staudinger M, Humpe A,Gramatzki M. et al. Strategies for purging CD96(+) stem cells in vitro and in vivo: New avenues forautologous stem cell transplantation in acute myeloid leukemia. [J]. Oncommun-logy. ,2013 2(6):e24500-e24500.

[5] Tettamanti,S.,Marin,V.,Pizzitola,I. et al. argeting of acute myeloid leukaemia by cytokine-induced killer cells redirected with a novel CD123-specific chimeric antigen receptor[J].British Journal of Haematology, 2013, 161(3): 389 -401.

[6] Günter Bernhardt. TACTILE becomes tangible: CD96 discloses its inhibitory peculiarities.[J].Nature immunology ,2014,15(5):406-408.

[7] Hwang,K.,Park,C.-J.,Jang,S. et al. Immunohisto chemical analysis of CD123, CD56 and CD4 for the diagnosis of minimal bone marrow involvement by blastic plasmacytoid dendritic cell neoplasm[J].Histopathology: Official Journal of the British Division of the International Academy of Pathology,2013,62(5):764-770.

[8] Christopher J Chan, Ludovic Martinet, Susan Gilfillan et al. The receptors CD96 and CD226 oppose each other in the regulation of natural killer cell functions.[J].Nature immunology,2014,15(5):431-438.

[9] DeSmet,D.,Trullemans,F., Jochmans,K. et al. Diagnostic potential of CD34+ cell antigen expression in myelodysplastic syndromes[J].American Journal of Clinical Pathology: Official Publication of American Society of Clinical Pathologists,2012,138(5):732-743. 
[10] Wilke, Vicki L.,Nettleton, Dan,Wymore, Meghan J. et al.Gene expression in intestinal mucosal biopsy specimens obtained from dogs with chronic enteropathy[J].American Journal of Veterinary Research,2012,73(8):1219-1229.

[11] Rollins-Raval,M.,Pillai,R.,Warita,K. et al.CD123 Immunohistochemical expression in acute myeloid leukemia is associated with underlying FLT3-ITD and NPM1 mutations[J].Applied immunohistochemistry and molecular morphology: AIMM,2013,21(3):212-217.

[12] Fromm, J.R..Flow cytometric analysis of CD123 is useful for immunophenotyping classical Hodgkin lymphoma[J].Cytometry, Part B. Clinical cytometry: the journal of the International Society for

Analytical

Cytology,2011,80B(2):91-99. 